\title{
UPAYA KREATIF SYAHRUR DALAM RANGKA MENGEMBALIKAN POSISI POLIGAMI SEBAGAI PROBLEM SOLVER (PENDEKATAN LINGUISTIK)
}

\author{
Mia Fitriah Elkarimah \\ Universitas Indraprasta PGRI Jakarta \\ el.karimah@gmail.com
}

\begin{abstract}
This paper discusses about Syahrur's linguistic approach on verse polygamy interprretation, there are 3 assumptions with this approach. First, there is no synonym (muradif) in Arabic. then he explore the text from etymology to morphology and redefines texts. Secondly, Syahrur rejects the idea of atomization (ta'diyah), even he interprets each verse of the Qur'an based on the assumption that each verse belongs to a single unit within a larger unitary entity in kitab. This method is called intratextuality method. Third, the syntagmatic-Paradigmatic he used is as the weapon in searching the meaning that existed in a text editor. The use of this analysis is helpful in shaping the formulation of different legal results from synchronous; searching for the structural relation of each element of language until Syahrur's attempt to trace the root of the word in the verse or called diakronis. the first result of the conclusion according to Syahrur is polygami depend on him that the solution of social problems is not the arena of the fulfillment of biological needs. Polygamy is considered a means to provide protection for widows who have orphans. Because of the rules that the second, third and fourth wives of a widow who has orphans. The second result is justice according to Syahrur is not fair to wives but children (children of husbands with orphans of married women).
\end{abstract}

Tulisan ini membahas pendekatan linguistik Syahrur pada ayat poligami, ada 3 pijakan Syahrur pada pendekatan ini. Pertama, tidak ada sinonim (muradif) dalam bahasa Arab, maka ia melakukan pembongkaran dari etimologi sampai morfologi dan meredefenisi teks. Kedua, Syahrur menolak pendapat tentang atomisasi (ta'diyah), maka ia menafsirkan masing-masing ayat Al-Qur'an berdasarkan asumsi bahwa masing-masing ayat dimiliki oleh sebuah unit tunggal dalam sebuah kesatuan unit yang lebih besar dalam al-Kitab. Metode ini dinamakan metode intratekstualitas. Ketiga, analisis Sintagmatik-Paradigmatik, 
digunakan Syahrur sebagai senjatanya dalam mencari dan mengejar makna yang ada pada sebuah redaksi teks. Penggunaan analisis ini sangat membantu syahrur dalam merumuskan hasil hukum yang berbeda dari mulai sinkronis; mencari relasi struktural tiap unsur bahasa sampai upaya Syahrur untuk melacak akar kata kunci dalam ayat tersebut atau disebut diakronis. Dampak dari pendekatan linguistik Syahrur pada ayat poligami adalah bahwa poligami adalah solusi permasalahan sosial bukan ajang pemenuhan kebutuhan biologis. Poligami dianggap sebagai sarana untuk memberi perlindungan bagi janda-janda yang mempunyai anak yatim. Karena syarat bagi pelaku poligami untuk mengambil istri kedua, ketiga dan keempat seorang janda yang memiliki anak yatim. Dan berlaku adil menurut Syahrur bukanlah berlaku adil kepada istri-istri melainkan anakanak (anak-anak suami dengan anak-anak yatim dari wanita yang dinikahi).

Keywords: Pendekatan Linguistik, Intertekstuaitas, Sintagmatik-

Paradigmatik, sinkronis-diakronis, anak-anak yatim

\section{Pendahuluan}

Islam melalui syariatnya adalah agama yang mengevaluasi kehidupan manusia untuk menghasilkan ketenangan, ketentraman dan kebahagiaan. Begitu juga dalam berumah tangga, banyak sekali evaluasi positif yang terkait dengan hal tersebut. Pernikahan dalam Islam menunjukkan pola bagaimana membangun keluarga yang indah menjadi satu lembaga. Poligami juga termasuk bentuk pernikahan yang sering diperbincangkan masyarakat. sekaligus kontroversial. Poligami adalah syariat Islam, dan juga dilakukan melalui pernikahan, cuma persepsi yang ada poligami identik pada sulitnya membangun dan menciptakan keluarga yang tenang dan tentram. Padabal Islam memberikan jaminan babwa selurub syariatnya diperuntukan untuk ketenangan manusia atau dengan kata lain untuk kemaslahatan manusia.

Dengan prinsip diatas jelaslah bahwa disyariatkannya poligami untuk kemaslahatan manusia, yakni untuk mewujudkan keluarga yang baik, bukan semata-mata untuk menyenangkan suami. Dari prinsip ini juga dapat dipahami bahwa jika poligami itu tidak dapat mewujudkan kemaslahatan, maka poligami tidak boleh dilakukan. 
Karena itulah, Islam memberikan aturan-aturan yang dapat dijadikan dasar untuk pelaksanaan poligami sehingga dapat terwujud kemaslahatan tersebut. Jika dikaji pemicunya bukan karena ketidakjelasan dalil melainkan manusianya yang tidak mengikuti 'aturan' yang dibolehkan, Poligami ibarat obat jika aturan mainnya tidak dipatuhi, besar kemungkinan obat itu justeru akan menjadi racun yang dapat mencelakakan peminumnya. Spirit dasar kebolehan poligami yang disalahgunakan oleh sebagian pihak, karena melihat bahwa kebolehan itu hanya pada tataran agama saja; yang hanya mengikat bagi yang sadar akan agama. Maka itu, Negara harus mengatur dan mengendalikan poligami agar tidak menjadi makhluk 'liar' yang mudah disalahgunakan.

Saat ini saja, praktik poligami banyak dilakukan oleh masyarakat dengan tidak lagi mengarah pada misi kemanusiaan dan keadilan. Hal ini diindikasikan dengan banyaknya kasus kekerasan dalam rumah tangga (KDRT) yang muncul ${ }^{1}$ serta masih banyaknya praktik poligami sirri dengan jumlah istri yang lebih dari empat. Oleh karena itu, para ulama' bekerjasama dalam upaya mengembalikan konsep poligami agar sesuai dengan tujuan idealnya. Upaya kreatif dalam rangka mengembalikan posisi poligami sebagai problem solver atas beberapa permasalahan yang terjadi di dalam kehidupan masyarakat adalah dengan memperberat persyaratan poligami sebagaimana yang dilakukan oleh para ulama' abad modern dan beberapa negara muslim. ${ }^{2}$

Muhammad Syahrur (yang selanjutnya penulis menyebutnya dengan Syahrur), ia seorang profesor pakar dalam bidang teknik sipil bagian pertanahan dan geologi. Ia menawarkan pembolehan poligami dengan ukuran yang rasional yang kriterianya mengandung unsur kemaslahatan dan nilai kemanusiaan yang tinggi. yaitu disyaratkan berpoligami harus dengan wanita yang

1. Agus Sunaryo, Poligami Di Indonesia (Sebuah Analisis Normatif-Sosiologis, Jurnal Studi Gender \& Anak, Vol.5 No.1 Jan-Jun 2010 Pp.143-167

2. Lilik Andaryuni, Poligami Dalam Hukum Keluarga Di Dunia Islam, Sipakalebbi’ | Volume 1 Nomor 1 Mei 2013, Hal. 110

TAJDID Vol. 17, No. 2, Juli - Desember 2018 |111 
statusnya janda posisi memiliki anak yatim. Seluruh analisa Syahrur diawali dengan pendekatan linguistik, ini dikuatkan dengan pendapatnya Ja'far Dek al-Bab seseorang yang ahli di bidang linguistik ketika mengungkapkan dalam kata pengantar di kitab perdananya Syahrur. ${ }^{3}$

Poligami sering ditinjau dari beberapa pendekatan, diantaranya pendekatan historis sosiologis, psikologis, dan sebaginya. Disini penulis ingin memaparkan poligami dilihat dari pendekatan linguistik, karena linguistik dalam hal ini memegang peran yang cukup penting dalam memahami teks-teks keagamaan. Teks-teks keagamaan yang termaktub dalam al-Qur'an maupun hadist nabi.

Linguistic dalam kajian teks al-Qur'an adalah kajian tentang hakikat, konsep dan fungsi Al-Qur'an sebagai teks bahasa, namun tidak berarti bahwa Al-Qur'an sama dan sejajar dengan teks-teks bahasa kemanusiaan lainnya. Sebaliknya, menurut Esack "penempatan Al-Qur'an sebagai teks bahasa tetap menempatkannya sebagai teks sakral berbahasa Arab yang di dalamnya mengandung mu'jizat abadi" .4

Menurut Zenrif pendekatan bahasa dalam kajian hukum Islam terutama masalah poligami, berarti menjadikan lafal-lafal AlQur'an yang disinyalir sebagai ayat eksistensi disyariatkan poligami sebagai obyek. ${ }^{5}$ Ayat-ayat tersebut haruslah dipahami dengan baik dan benar, Pemahaman tentang poligami diawali dari pemahaman dari sudut kebahasaan sangat diperlukan.

Penulis tertarik dengan pendekatan linguistiknya Syahrur dalam mengkaji teks Al-quran, karena berbeda dengan ulama

3. Syahrur, al-Kitab Wa Al-Qur'an; Qira'ab Mu'ashirah, Damaskus ; al-Ahali li at-Tiba'ah Wa al-Nashr Wa al-Tauzi':1992), hal. 19-27.

4. Farid Esack, Samudera Al-Qur'an. terj Nuril Hidayah. cet 1. Yogyakarta: Diva Press. 2007), hal.:41-42.

5. Zenrif,Mf. Sintesis Paradigma Studi Al-Quran. Malang : UIN Malang Press,2008), hal. 51

112 | TAJDID vol. 17, No. 2, Juli - Desember 2018 
klasik, dimulai dari merombak cara pandang terhadap Al-Quran sebagai obyek studi ilmiah, dengan berkeyakinan al-Qur'an adalah kalam Tuhan yang suci bebas ruang dan waktu dan berdimensi sakralitas dalam arti pada teks al-qur'an tidak mungkin berubah, namun teks Al-qur'an memiliki wujud sifat kebahasaan yakni terkait dengan pemikiran dan realitas sosial yang memiliki dimensi ruang dan waktu. Sehingga Syahrur mengarah bahwa Al-Qur`an adalah dari Tuhan, bersifat absolut dan memiliki kesempurnaan pengetahuan dan tidak memiliki sifat relatif, namun pada sisi pemahaman teks Al-qur'an (al-fahm al-Insani) ia harus memuat unsur-unsur yang relatif sesuai dengan perjalanan waktu. ${ }^{6}$

Argumentasi Al-Qur'an bersifat relatif dimaksudkan Syahrur bahwa Al-Qur'an realitas ilahiyah yang abadi. Namun, pada sisi pemahamannya (al-fahm al-Insani) ia harus memuat unsur-unsur yang harus selaras dengan konteks zaman dan perkembangan ilmu pengetahuan. Dengan kata lain, pemahaman manusia terhadap realitas ilahiah tersebut, sesuatu yang bisa berubah, bukan harus terjebak pada pemahaman tekstual-literal yang menyebabkan ajaran Islam yang dinamis dan universal hilang.

Pendekatan bahasa Syahrur dalam kajian teks Al-Qur'an ternyata membongkar dan merombak dan berimplikasi pada kesimpulan baru, karena menurutnya tidak relevan dengan zaman sekarang ini. Langkah pertama Syahrur pada pendekatan ini adalah rekonstruksi etimologi sebuah kata, lalu dianalisis dari sudut morfologi dan selanjutnya meredefinisi makna. Setiap memberi makna terhadap kata-kata yang ada dalam ayat ia selalu memberi alasan-alasan secara ilmiah berdasarkan ayat-ayat lain (interteks), ketika teks yang sama dalam ayat lain ia kumpulkan lalu ia analisis dari sudut struktural ( sintagmatis) dan sudut sistemis ( paradigmatis). 
Dari kesimpulannya dengan menggunakan pendekatan ini ternyata bertolak belakang dengan pandangan jumhur ulama klasik dan kontemporer, sehingga sejumlah respon datang bertubitubi. Disinilah ketertarikan penuilis untuk mengungkap pendekatan bahasa Syahrur dalam mengkaji teks poligami.

Model penelitian ini adalah sepenuhnya studi kepustakaan, terkait dengan pendekatan bahasa Syahrur. Dalam hal ini data primer adalah karya master piece syahrur, berjudul al-Kitab wal alQur'an ; Qira'ah Muashirah dan buku Nabwa Ushul Jadidah li al Fiqh al Islamy: figh Al Mar'ah. Penelitian ini menggunakan paradigma penelitian kualitatif, untuk memahami konsep poligami yang ditawarkan Muhammad Syahrur, penulis akan menjelaskan kerangka metodologi serta pendekatan linguistiknya dalam mengkaji teks Al-Qur'an yang berkaitan dengan poligami, dengan berupaya memaparkan secara jelas konsep-konsepnya. Selanjutnya, mempertemukan ayat-ayat dengan didasarkan pada satu pembahasan. Kemudian memetakan konstruk metodogis penafsirannya pada ayat tersebut dengan kamera linguistik. Mengingat penelitian ini adalah upaya menggali konsep poligami Syahrur. Maka pendekatan linguistiknya akan sangat membantu untuk memperjelas tawaran yang diusungkannya terhadap kasus poligami.

\section{Konsep Bahasa Syahrur}

Syahrur dalam mengkaji teks Al-Qur'an menggunakan berbagai macam pendekatan, diantaranya; saintifik, bahasa dan filosofis. Sedangkan penulis hanya membatasi satu pendekatan yaitu pendekatan linguistik. Seperti yang ditegaskan Haris ${ }^{7}$ bahwa "pendekatan bahasa yang diambil oleh Syahrur ini sebenarnya hanya digunakan untuk membangun suatu landasan teori dalam rangka penafsiran ulang terhadap tema-tema yang terdapat dalam

7. Pembongkaran Muhammad Syahrur Terbadap Islam Ideologis, Sebuah Pengantar atas ide-ide Pemikiran Islam Kontemporer dalam Al-Kitab Wa Al-Qur'an : Qira'ah Mu'asyirah. dalam Jurnal Ijtihad No. 1 Tahun III/Januari-Juni 2003, hal. 46

114 | TAJDID vol. 17, No. 2, Juli - Desember 2018 
Al-Qur'an sesuai dengan konteks ruang dan waktu abad kedua puluh".

Pendekatan linguistik dalam kajian teks Al-qur'an bukanlah barang baru. tetapi sudah lama dipraktekkan oleh ulama klasik. Perbedaan yang cukup tajam adalah ketika pendekatan linguistik Syahrur dalam kajian teks Al-qur'an hanya sekedar bahasa, dan tanpa faktor lain atau kaidah-kaidah yang disepakati ulama ketika ingin mengkaji Al-Qur'an. Contoh ketika Syahrur menolak konsep asbabul wurud, menolak konsep nasikh-mansukh (abrogasi), Ia Juga menolak penjelasan hadis atau pemahaman sahabat. Dan ia juga menolak ta'wil (tafsir) mufassir sebelumnya ${ }^{8}$

Perbedaan pendekatan linguistik Syahrur, sebagimana dijelaskan oleh Syamsuddin ( lebih berorientasi pada pendekatan Semantik dengan analisa Paradigmatis dan Sintagmatis dengan teknik intratekstualitas. ${ }^{9}$ Selain itu juga Syahrur juga mengikuti kebahasaan al-Jurjani yang tidak mengakui sinonimitas, untuk itulah ia mengacu pada kamus Maqayis al-Lughah karya Ibnu Faris yang jelas menolak sinonimitas, analisis sinkronik ini juga sangat kuat ini terlihat dari pernyataan-pernyataan Syahrur yang secara tidak langsung mencerminkan asumsi dasar tersebut. Misalnya, dia mengatakan "bahwa dalam menafsirkan al-Qur'an harus memandangnya seakan-akan ia baru saja diwahyukan untuk generasi kita". ${ }^{10}$

Berangkat dari pendekatan diatas, Disini peneliti akan memaparkan satu-persatu pendekatannya; Pertama, konsep Syahrur pada diakronik dan sinkronik yang muaranya pada penolakan sinonimitas, kemudian meredifinisi terminologi sejumlah kata yang bersinonim, dengan menelusiri text Al-Qur'an yang menjadi

8. Nahw Ushul Jadidah Li al-Figh al-Islami: Fiqh al-Mar'ah. Damaskus: alAhali li at-Tiba'ah Wa al-Nashr Wa al-Tauzi'. Cet. I, , 2000, hal. 44.

9. Metode Intratekstualitas Mubammad Shabrur dalam Penafsiran al-Qur"an, dalam Abdul Mustaqim dan Sahiron Syamsuddin (ed), 2002, Studi Al-Qur'an Kontemporer.Yogyakarta: Tiara Wacana 2002, hal. 9

10. Syahrur, 1992: 53

TAJDID Vol. 17, No. 2, Juli - Desember $2018 \mid 115$ 
rujukan atau dasar pengambilannya. Sebelumnya perlu dikemukakan dahulu konsepsinya tentang peristilahan di seputar istilah ayat-ayat poligami itu sendiri.

Sinonim merupakan salah satu objek kajian semantik yang membahas sebuah kata yang memiliki kesamaan makna antar suatu ujaran dengan ujaran lainnya. Secara etimologi kata sinonim berasal dari bahasa Yunani kuno, yaitu onoma yang berarti 'nama', dan syn yang artinya 'dengan'. Jadi, secara harfiah kata sinonim berarti 'nama lain untuk benda atau hal yang sama'.

Bahasa arab mengenal sinonim dengan istilah (al-mutarädif) dan semua sepakat dengan keberadaannya. Berbeda ketika eksistensi sinonim di dalam al-Qur'an, ada dua pandangan mengenai hal ini. Pandangan yang menetapkan adanya sinonim dalam al-Qur'an dan pandangan yang menolak. Yang menetapkan sinonim mereka berpandangan banyaknya simbol dengan satu makna sebagai bagian dari kemu'jizatan al-Qur'an dari sisi keindahan sastranya. Sedangkan kelompok yang menolak menganggap banyaknya simbol hanya dengan satu makna adalah bertentangan dengan kemu'jizatan al-Qur'an dari sisi keluasan hikmahnya. Dimana Allah tidak mungkin menciptakan banyak simbol hanya dengan satu makna saja, bila diteliti secara cermat ternyata masing-masing kosa kata dalam al-qur'an walaupun tampak bersinonim, itu mempunyai konotasi sendiri-sendiri. ${ }^{12}$

Eksistensi Sinonimitas dalam Al-qur'an ini sudah sejak lama diperdebatkan oleh ahli-ahli bahasa Arab. Sebagian dari mereka berpendapat bahwa sinonim dapat ditemukan dalam al-Qur'an, sementara yang lain mengatakan sebaliknya. Perbedaan pendapat ini, bermuara pada perbedaan jawaban atas pertanyaan apakah teks al-Qur'an itu mutlak formulasi dari Tuhan baik teks dan hal. 83).

11. Chaer, Pengantar Semantik Bahasa Indonesia. Jakarta: Rineka Cipta, 2009,

12. Nashruddin Baidan, Wawasan Baru Ilmu Tafsir, cet 1. Yogyakarta: Pustaka Pelajar, 2005 , hal. 317-318.

116 | TAJDID vol. 17, No. 2, Juli - Desember 2018 
maknanya, ataukah ada konstruksi manusia, meskipun kandungannya bersifat ilahi.

Sedangkan Syahrur berpendapat setiap kalimat dalam alQuran memiliki makna yang spesifik atau lebih dari satu makna, hal tersebut sebagai bukti kemukjizatan dan keagungan al-Quran yang relevan di setiap ruang dan waktu. Dan yang mengatakan kalimat-kalimat al-Quran memiliki makna yang sama atau mirip adalah keliru. Sehingga ia merekonstruksi sejumlah kata yang oleh mayoritas dipandang sebagai sinonim, seperti imra'ab-untsa-nisa', walad-ibn, al insan-al basyar, fu'ad-qalb, al Qur an-alKitab-al Driker, dan lain-lain.

Bila kita cermati, konsep asinonimitas yang diambil oleh Syahrur ini sebenarnya hanya digunakan untuk membangun suatu landasan teori dalam rangka penafsiran ulang terhadap tema-tema yang terdapat dalam Al-Qur'an sesuai dengan konteks ruang dan waktu abad kedua puluh. ${ }^{13}$

Dalam menganalisa makna-makna al-Qur'an, Syahrur tampaknya menerapkan paradigmo-sintagmatik -penerjemah meminjam istilah tersebut dari Osborne dalam bukunya The Hermeneutical Spiral_- Analisa paradigmatik adalah sebuah analisa bahasa yang digunakan seseorang untuk memahami makna kata dengan cara membandingkannya dengan kata-kata lain yang memiliki kemiripan makna atau justru memiliki makna yang bertentangan. ${ }^{14}$

Sedangkan analisa sintagmatis, yaitu memandang makna setiap kata pasti dipengaruhi oleh kata-kata sebelum dan sesudahnya yang terdapat dalam satu rangkaian ujaran. Dengan pendekatan ini, suatu konsep terma keagamaan tertentu bisa

13. Haris, 2003, hal. 46.

14. Sahiron Syamsuddin, Metode Intratekstualitas Muhammad Shabrur dalam Penafsiran al-Qur"an, dalam Abdul Mustaqim dan Sahiron Syamsuddin (ed), 2002, Studi Al-Qur'an Kontemporer.Yogyakarta: Tiara Wacana, hal. 128

TAJDID Vol. 17, No. 2, Juli - Desember $2018 \mid 117$ 
dideteksi dengan memahami kata-kata disekeliling terma tersebut. Adapun setelah menggunakan analisa di atas, Syahrûr mengkaji ayat-ayat al-Qureên dan mengambil kata-kata kunci yang terdapat pada setiap topik bahasan, yang dalam istilah Syahrur disebut dengan "at-tartil".

Dari uraian singkat tentang pendekatan linguistik yang digunakan Syahrur, dapat kita ketahui bahwa Syahrur merekonstruksi beberapa makna, terlebih pemaknaan al-Qur'an, tapi keseluruhan rekonstruksi itu ia hadirkan untuk menjadikan ajaran Islam relevan / shalihun likulli zaman wa makan.

\section{Pendekatan Bahasa Syahrur Pada Ayat Poligami}

Ayat yang dijadikan dasar hukum poligami ialah Surat al Nisa' [4]: 3.32

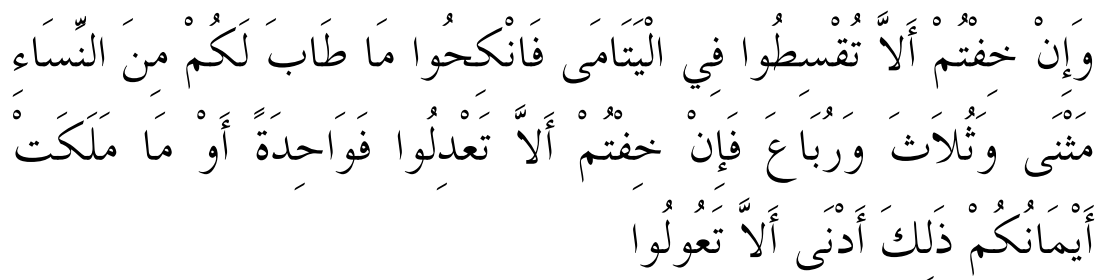

Ayat poligami menurut Syahrur termasuk ayat risalah, risalah yang dimaksud bukan seperti istilah disepakati umat Islam. Tetapi satu dari pembagian syahrur pada beberapa sinonim Al-Qur'an. Al-Qur'an dalam istilah Syahrur hanya mencakup salah satu bagian dari al-Kitab, sedangkan Al-Kitab menurut nya adalah alqur'an yang kita fahami, yang dimulai dari surat al-Fatihah dan diakhiri surat al-Naas. Di dalamnya ada ayat mutasyabihat yang berdimensi al-nubuwwah dan ada ayat muhkamat yang berdimensi al-risalah. Risalah ini yang dimaksud syahrur adalah satu bagian dari al-kitab yang bersifat subjektif dan terkandung kumpulan hukum dari aspek ibadah, mu'amalah, akhlak, dan hukum halal haram. Bersifat subjektif dalam arti hukumnya sesuai dengan kondisi dan situasi sosial zamannya yang menyebabkan keniscayaan penafsiran yang relatif. 
Dengan paparan di atas terlihat sekali bahwa syahrur secara mutlak menafikan sinonim dibuktikan dengan membedakan istilah al-Kitab dan al-Qur`an. Padahal jumhur mengatakan term alQuran, al-Kitab memiliki arti yang sama satu sama lain. ${ }^{15}$ Rujukan Syahrur ketika membedakan Al-Qur'an berbeda dengan al-Kitab, berdasarkan pada surah al-Hijr/15: 1

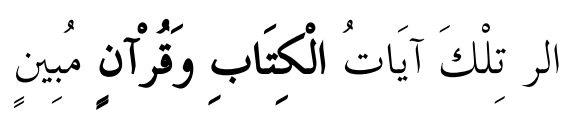

Kata al-Qur`an pada ayat itu di ataf-kan dengan al-Kitab, sementara menurut kaidah bahasa, ’ataf memiliki dwi fungsi; Pertama, li at-taghayyar yakni menunjukan antara ma'tuf dengan ma'tuf 'alaibi ada perbedaan; Kedua, 'ataf al-khass 'ala al-'amm. Artinya apa yang disebutkan secara khusus itu penting dan merupakan bagian dari yang umum. Ini menunjukkan adanya variabel antara satu sama lain, atau untuk menunjukkan yang khusus atau yang umum;. Dalam ayat tersebut menurut Syahrur huruf ataf yang pertama berfungsi sebagai (li al-taghayur) berarti alQur'an dan al-Kitab merupakan dua substansi yang berbeda, sedangkan huruf ataf yang kedua berarti al-Qur'an merupakan salah satu dari al-kitab. ${ }^{16}$

Ayat poligami ini termasuk ayat-ayat hududiyah yang dalam istilah Syahrur penafsiran bisa berubah sesuai dengan perubahan kondisi zaman yang penting masih berada dalam wilayah batasbatas hukum Allah ta'ala. ${ }^{17}$ Asumsi dasarnya adalah bahwa Allah di dalam Al-Qur'an telah menetapkan hudud dalam berbagai ketentuan hukum, baik yang maksimum maupun yang minimum dalam istilah syahrur.18 Inilah wilayah ijitihad manusia, elastisitas dan fleksibilitas hukum Allah tadi dapat digambarkan seperti posisi pemain bola yang bebas bermain bola, asalkan tetap berada pada

\footnotetext{
15. Syahrur, 1992:54.

16 Ibid., hal. 58

17. Ibid., hal 55

18. Ibid., hal 144
}

TAJDID Vol. 17, No. 2, Juli - Desember 2018 |119 
garis-garis lapangan yang telah ada. Pendek kata, selagi seorang muslim masih berada dalam wilayah Hudud (ketentuan Allah antara batas minimum dan maksimum tadi), maka dia tidak dapat dianggap keluar dari hukum Allah. ${ }^{19}$

Setelah mengetahui kategori ayat diatas, Syahrur beranjak pada analisis makna adil dalam ayat ini, syahrur mencoba mernbedakan 2 hal penting qasata dan 'adala. Menurut Shahrur dalam magnum opus-nya Nahwa Ushul Jadidah li al Fiqh al Islamiy Figh al Mar'ah (2000) asal kata qasata dalan' bahasa arab adalah menunjukkan sesuatu yang memiliki dua pengertian yang bertolak belakang. Arti yang pertama keadilan dan pertolongan, sedangkan arti kedua adalah kezaliman dan penindasan.

Berikut ini penulis memaparkan bagaimana Syahrur mempertemukan ayat-ayat ini dengan didasarkan makna yang sama, berikut ini kata qasata yang bermakna keadilan dan pertolongan sebagaimana firman Allah pada Q.S. al-Mâidah/5:42, al-Hujarât/49:9, al-Mumtahanah/60:8.

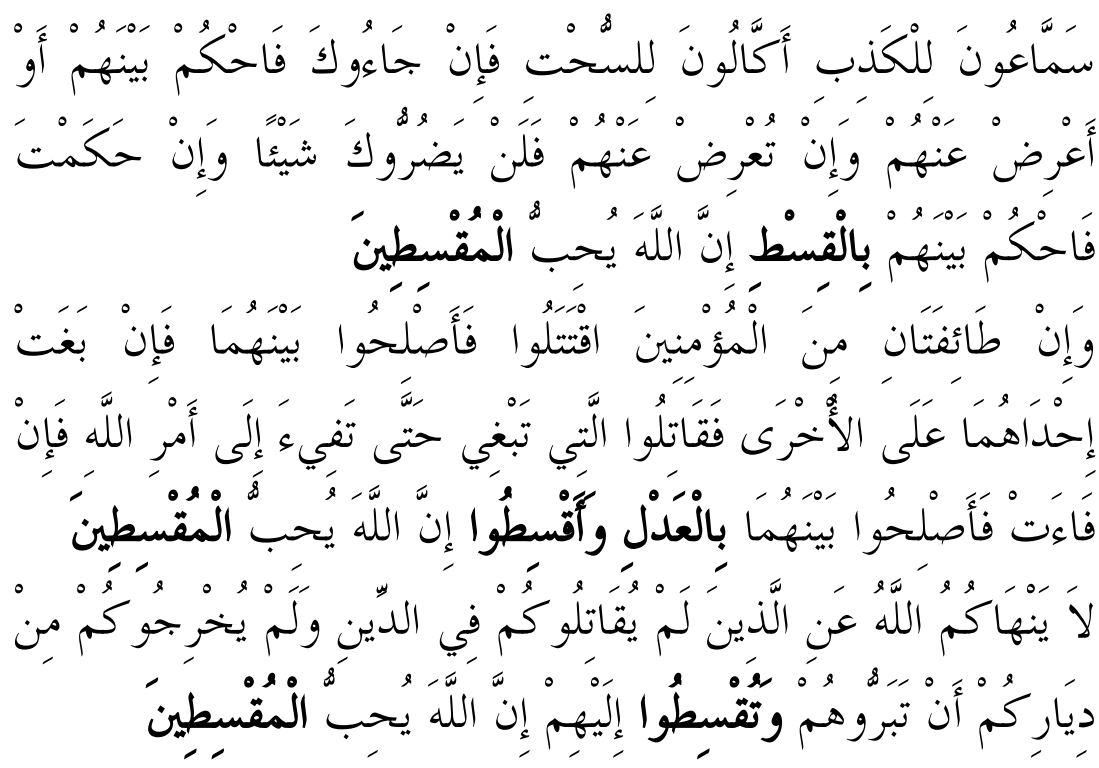

19. Ibid., hal 144

120 | TAJDID vol. 17, No. 2, Juli - Desember 2018 
kata qasata yang bermakna adalah kezaliman dan penindasan sebagaimana firman Allah pada Q.S. al-Jinn/72:14..

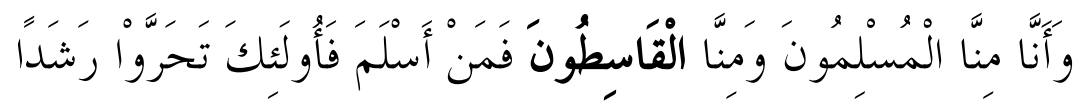

Dan sesunggubnya di antara kami ada orang-orang yang taat dan ada (pula) orang-orang yang menyimpang (Al-qosituna) dari kebenaran. Barangsiapa yang taat. Maka mereka itu benat-benar telah memilih jalan yang lurus'

Begitu pula kata al-'adl, mempunyai dua arti yang berlainan, bisa berarti al-istiwa' (baca sama, lurus) dan juga bisa berarti ala'waj (bengkok).

Menurut Syahrur ayat poligami ini adalah ma'tuf dengan ayat sebelumnya, karena terdapat ungkapan in, yang maknanya jika. Ayat sebelumnya berbicara tentang hak-hak anak yatim. Allah berfirman

"Dan berikanlab kepada anak-anak yatim (yang sudah balig) harta mereka, jangan kamu menukar yang baik dengan yang buruk dan jangan kamu makan barta mereka bersama hartamu. Sesunggubnya tindakantindakan (menukar dan memakan) itu, adalab dosa yang besar"(AlNisā'/4:2).

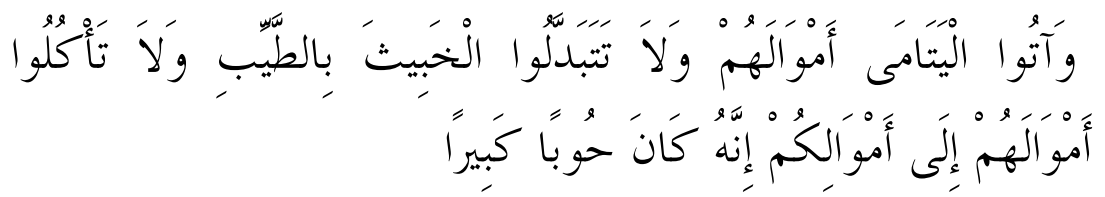

Lafaz الْيتًَامَى dalam ayat poligami dalam Surat al Nisa’ menurut Syahrur berarti anak-anak yatim dari janda yang ditinggal mati "ibu anak yatim" bukan anak-anak yatim yang akan dinikahi sebagaimana penjelasan jumhur ulama. ${ }^{20}$ 
Kemudian yang dimaksud dengan

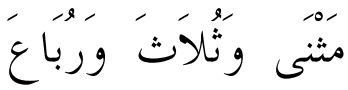
adalah janda-janda yang mempunyai anak yatim 2, 3, atau $4 .{ }^{21}$ Bersebrangan dengan jumhur yang menafsirkan dengan wanita kedua, wanita ketiga atau wanita keempat ; baik berupa gadis atau janda, baik janda yang ditinggal mati suaminya atau janda yang dicerai, baik janda yang mempunyai anak maupun janda yang tidak mempunyai anak. ${ }^{22}$

و وَإن Dyalam hal ini Syahrur menghubungkan redaksi syarat

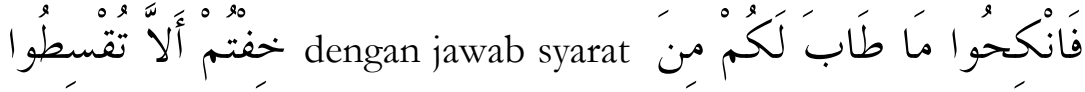
sehingga dapat dipahami ayat ini tidak mensyaratkan kualitas bagi istri pertama sehingga terbuka kebebasan untuk memilih janda atau perawan. Akan tetapi agar tercapai keserasian ayat antara jawab syarat dengan syarat adil terhadap anak-anak yatirn, maka wajib dipahami bahwa ayat ini berbicara tentang ibu dari anak-anak yatim (janda yang punya anak). Dengan demikian istri kedua, ketiga dan keempat adalah janda yang punya anak.

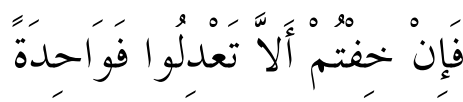

Sedang yang dimaksud kata الا تعدلو menurut Syahrur adalah adil antara anak-anak (anak-anak dari suami dan anak-anak dari janda yang yang ditinggal mati yang dinikahi). ${ }^{23}$ Sedangkan menurut jumhur ulama adalah adil antara istri-istri.

Dalam hal ini tampak jelas, jika menggunakan makna adil dengan kata ta'dilu dimaksudkan adil di antara anak suami dan

21. Ibid., hal, 599

22. Wahbah al Zuhaili, Al-Tafsir al-Munir fi al- Aqidah wa al-Syari ah wa alManbaj. Beirut: Dar al-Fikr al-Mu`ashir, 1991, hal 237

23. Ibid., hal, 599

122 | TAJDID vol. 17, No. 2, Juli - Desember 2018 
anak-anak yatim, sedangkan adil dengan kata taqsitu anak-anak yatim saja. ${ }^{24}$ Disinilah Syahrur membedakan perbedaan kata alqasth dengan al-'adl. Al-qasth bisa dari satu sisi saja, sedang al-'adl harus dari dua sisi. ${ }^{25}$ Ini berbeda dengan pendapat ulama yang memaknai sama antara dua kata tersebut.

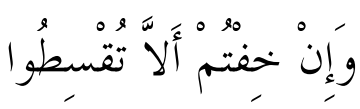

Jika kamu takut tidak dapat berlaku adil pada anak-anak yatim itu maka satu saja.

Dilihat dari teks ayat, apa yang dikatakan Syahrur ini cukup beralasan, karena susunan kata yang menggunakan kata adil tidak menunjuk pada satu orang tertentu melainkan dua orang atau lebih, sedangkan kata tuqsitu mengenai satu arah yaitu anak-anak yatim saja.

Sehingga tafsiran Syahrur "apabila tidak bisa berlaku adil antara anak-anak (anak-anak suami dengan anak-anak yatim dari janda yang dinikahi), maka nikahilah janda satu saja yang mempunyai anak yatim sebagai istri kedua,

Di samping itu menurut Syahrur pihak yang menjadi pembicarar dalam ayat ini, adalah orang yang sudah rnemiliki satu istri, maka. Redaksi ayat dimulai dengan kata masna (kedua). Dengan demikian dimaksud kata فو احدة dalam ayat di atas adarah istri kedu, bukan istri pertama. Sedangkan menurut jumhur, kata berarti istri satu saja (istri pertama), Maksudnya adalah bertahanlah dengan satu istri saja, tidak perlu menambah istri lagi, bila tidak sanggup berbuat adil di antara istri-istrinya.

Pengertian syahrur ini diperkuat lagi dengan sambungan ayat

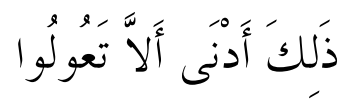

24. Ibid.,

25. Syahrur, 2000, hal 598

TAJDID Vol. 17, No. 2, Juli - Desember $2018 \mid 123$ 
Kata تَعُولُوُ berasal dari kata عول yang berarti banyak tanggungan (anak) dan banyak melakukan ketidakadilan. Seorang laki-laki yang memiliki banyak tanggungan (anak dan istri) purya kewajiban secara financial dan pendidikan pada anak-anaknya, rnaka jika ia tidak mampu mengemban tanggung jawab ini, ia akan menelantarkan mereka.

Dari makna kata-kata pada surah an-Nisa'/4:3, dengan menggunakan analisa sintagmatik-paradigmatik maka diterjemahkan menurut Syahrur sebagai berikut :

Apabila kamu takut tidak dapat berbuat adil terbadap anak-anak yatim (dari janda yang kamu nikahi), maka nikahilah wanita-wanita (janda yang mempunyai anak yatim) dua, tiga, atau empat. Dan apabila kamu takut tidak bisa berbuat adil (antara anak-anak kamu dan anakanak yatim dari janda yang kamu nikahi), maka nikabilah satu (dari janda-janda yang mempunyai anak yatim itu) atau budak yang kamu miliki yang demikian itu lebih dekat untuk tidak berbuat keji.

Demikian juga tentang mahar, menurut Syahrur bagi laki laki yang berpoligami ini diberikan Allah keringanan untuk tidak membayar mahar dengan syarat dia mau menanggung hidup anak yatim, lagi-lagi asumsi dasar Syahrur adalah teks Al-Qur'an, sebagaimana tertera pada surah al-Nisa: $127 .^{26}$

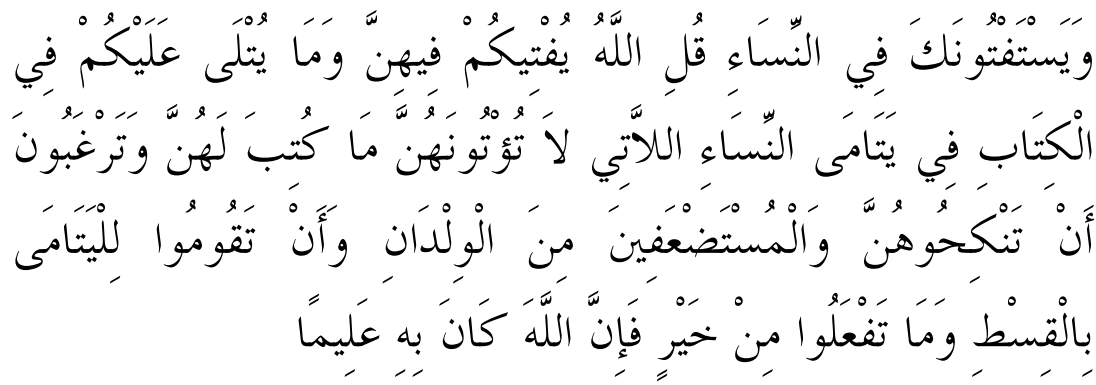

Menurut Syahrur dalam berpoligami ini Allah swt tidak mewajibkan adil terhadap istri pertama dan selanjutnya. Tetapi

26. Ibid., hal, 600

124 | TAJDID vol. 17, No. 2, Juli - Desember 2018 
yang dimaksudkan adalah adil terhadap anak-anak suami (dari istri pertama ) dan anak-anak yatim dari ibu yang dinikahinya. Ini dikuatkan pendapatnya dengan ayat surah an-nisa : 129 bahwa “ tidak bisa adil pada istri-istrimu" . karena yang dimaksudkan adil adalah anak-anak yatim dan anaknya. Keadilan ini yang bisa diterapkan bagi seorang laki-laki, sedangkan kedilan antar sesama istri tidak bisa diterapkan apalagi adil dalam hal cinta dan kasih sayang.

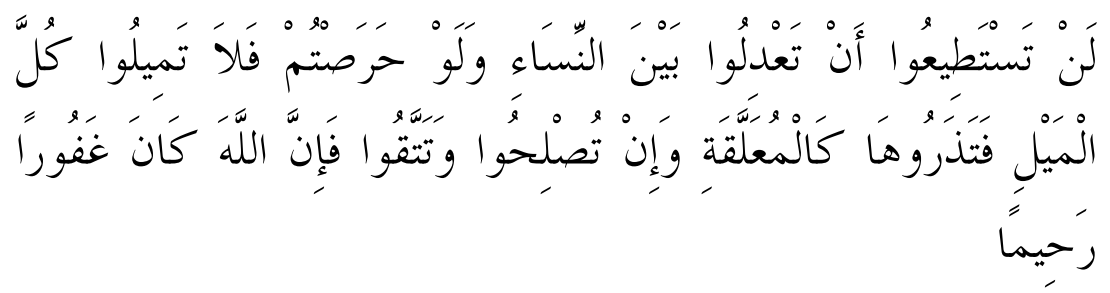

Disinilah letak kesinambungan analisanya Syahrur pada ayat poligami yang berdasarkan susunan teks. Dengan menggunakan analisa paradigmatis dan sintagmatis dengan teknik intratekstualitas, syahrur mulai meredefinisi terminologi sejumlah kata yang bersinonim, kemudian menelusuri text Al-Qur'an yang menjadi rujukan atau dasar pengambilannya, dan mempertemukan ayatayat dengan didasarkan pada makna yang sama. tanpa terpengaruh pada pendapat, mazhab, dan metodologi ulama klasik. Intinya ia memandang ayat poligami dalam konteks kekinian. Baginya dengan perspektif inilah penafsiran Al-Qur'an bisa diterapkan untuk segala waktu, zaman dan tempat sehingga penafsiran AlQur'an bisa digunkakan untuk keperluan konteks hidup sekarang.

\section{Kesimpulan}

Poligami memang menjadi bagian dari syari'at Islam. Memahami poligami dalam Islam, tidak cukup hanya dengan mengartikan satu ayat secara tekstual, ayat-ayat Al-Qur'an harus dipahami secara menyeluruh dan holistik. Implikasi pendekatan linguistic Syahrur mampu menampilkan kesimpulan hukum yang baru.

TAJDID Vol. 17, No. 2, Juli - Desember $2018 \mid 125$ 
Syahrur mengkombinasikan ayat baik sebelum dan sesudah dengan analisa paradigmatis dan sintagmatis dengan teknik intratekstualitas lalu ia tafsirkan dengan konteks kekinian Dia tidak mau terikat dalam pola pikir klasik. Dari pendekatan tersebutlah muncul kefahaman akan adanya pelibatan janda yang memiliki anak sebagai istri kedua, ketiga dan keempat. keadilan diantara para anak dari istri pertama dan anak-anak yatim para janda yang dinikahi berikutnya.

Di sinilah pendapat Syahrur tentang poligami layak dipertimbangkan, karena Poligami sebuah legalitas tapi kadang pelaku nya abu-abu dalam memahami sebuah legalitas ini. ada yang semata-mata untuk melegalkan nafsu yang nakal, akhirnya poligami ini menjadi solusi.

\section{Daftar Pustaka}

Abdurrahman. 1992. Kompilasi Hukum Islam di Indonesia. Jakarta: Akademika

Ahmad Rofiq. 1997. Hukm Islam di Indonesia, Jakarta: PT Raja Grafindo Persada,

al-Zuhaili, Wahbah. 1991. Al-Tafsir al-Munir fi al-Aqidah wa alSyari ah wa al-Manhaj. Beirut: Dar al-Fikr al-Mu`ashir

Baidan, Nashruddin. 2005. Wawasan Baru Imu Tafsir, cet 1.

Yogyakarta: Pustaka Pelajar

Chaudhari, Muhammad Syarif. 1997. Women's Right in Islam, New

Delhi : Adam Publiser. Pressindo. Cet. I.

Chaer, Abdul. 2007. Linguistik Umum. jakarta: Rineka cipta 2009.Pengantar Semantike Babasa Indonesia.

Jakarta: Rineka Cipta

Christmann, Andreas. 2004. The Form Is Permanent But The Content Moves: The Qur'anic Text And Its Interpretation Mohammad Syahrour's Al-Kitab Wal-Qur'an, dalam Suha Taji-Farouki (ed.), Modern Muslim Intellectual And The Qur'an. New York: Oxford University press.

126 | TAJDID vol. 17, No. 2, Juli - Desember 2018 
Esack, Farid. 2000. Al-Qur'an, Liberalisme, Pluralisme; Membebaskan Yang Tertindas: Authors, terj. Watung A. Budiman. Bandung: Mizan, 2000

Hidayah. cet 1. Yogyakarta: Diva Press.

Haeratun. 2014. Legalitas Poligami Menurut Perspektif Hukum Islam Dan Hukum Positif (Uup Nomor 1 Tahun 1974 Pelaksanaan Pp Nomor 9 Tahun 1975 Dan Khi), Ganeç Swara Vol. 8 No.2 September 2014

Haris, Abdul. 2003 . Pembongkaran Muhammad Syahrur Terbadap Islam Ideologis, Sebuah Pengantar atas ide-ide Pemikiran Islam Kontemporer dalam Al- Kitab Wa Al-Qur'an : Qira'ab Mu'asyirah. dalam Jurnal Ijtihad No. 1 Tahun III/Januari-Juni

Kurzman, Charles. 2001. Wacana Islam Liberal; Pemikiran Islam Kontemporer Tentang Isu-Isu Global, terj. Bahrul Ulum dan Heri Junaidi. Jakarta. Paramadina

Mulia, Musdah. 1999. Paadangan Islam tentang Poligami. Jakarta: lembaga kajian agama dan gender

Mustaqim, Abdul dan Syamsuddin, Sahiron (ed.). 2003. Mempertimbangkan Metodologi Tafsir Muhammad Syahrur", Hermenutika al-Qur'an, Madz̧hab Yogya, Yogyakarta: Forstudia Islamika.

-----. 2002 .Metode Intertektualitas Muhammad Syahrur Dalam Penafsiran Al-Qur'an'. Studi Al-Qur'an Kontemporer: Wacana Baru Berbagai Metodologi Tafsir. Yogyakarta: Tiara Wacana

Syahrur, Muhmmad. 2004. Prinsip dan Dasar Hermeneutika AL-

Quran Kontemporer. Ter. Sahiron Syamsuddin dan Burhanuddin Dzikir. Yogyakarta: ElSAQ Press

-----,2010. Metodologi Fiqih Islam Kontemporer, ed. Sahiron Syamsuddin. Yogyakarta: eLSAQ Press

, 2000. Nahw Ushul Jadidah Li al-Figh al-Islami: Fiqh al-Mar'ah. Damaskus: al-Ahali li at-Tiba'ah Wa al-Nashr Wa al-Tauzi'. Cet. I

TAJDID Vol. 17, No. 2, Juli - Desember $2018 \mid 127$ 
Mia Fitriah Elkarimah

-----,1992. al-Kitab Wa Al-Qur'an; Qira'ah Mu'ashirah, Damaskus ; al-Ahali li at-Tiba'ah Wa al-Nashr Wa al-Tauzi'.

Syamsuddin, Sahiron. 2003. Hermneutika Mą̧ab Yogya, Yogyakarta: Islamika,

------,2002, Metode Intratekstualitas Muhammad Shabrur dalam Penafsiran al-Qur"an, dalam Abdul Mustaqim dan Sahiron Syamsuddin (ed), 2002, Studi Al-Qur'an Kontemporer.Yogyakarta: Tiara Wacana.

128 | TAJDID vol. 17, No. 2, Juli - Desember 2018 